\title{
Diurnal variations in canine hematological parameters after commercial feed feeding
}

\section{Variações diurnas nos parâmetros hematológicos caninos após alimentação com ração comercial}

\author{
Letícia Ramos Costa $^{1}$; Nathalia Lopes Tavares da Silva ${ }^{2}$; Paula Lima de Oliveira ${ }^{1}$; \\ Natália Camila Minucci Bonatto ${ }^{3}$; Guilherme Coutinho Vieira ${ }^{4}$; \\ Beatriz Perez Floriano5; Luiz Daniel de Barros ${ }^{6}$; Maria Rachel Melo Bosculo ${ }^{7}$; \\ Breno Fernando Martins de Almeida ${ }^{5 *}$
}

\section{Highlights:}

Food intake is responsible for the increase in leukocyte count in dogs; Dogs show increased segmented neutrophils and decreased lymphocytes after ingestion of commercial feed; After food intake, dogs demonstrate a decrease of red cells, hemoglobin concentrations, hematocrit and mean corpuscular volume;

Food intake resulted in decreased total plasma protein in dogs.

\begin{abstract}
Complete blood count $(\mathrm{CBC})$ is the evaluation of blood cells, which provides resourceful information. Considering that inadequate fasting time is the most common pre-analytical error in laboratory diagnosis and is associated with lipemia in blood samples, which has not yet been adequately investigated in dogs, this study aimed to assess diurnal postprandial changes in the $\mathrm{CBC}$ of healthy dogs fed with industrialized feed. Eighteen clinically healthy dogs aged 2-6 years and weighing over $6 \mathrm{~kg}$ were enrolled in the study. All dogs received "Premium" industrialized feed every 12 hours. Blood was collected after a 12-hour fasting period at 6:00 am (baseline), followed by feeding and new blood samples collected hourly for the next 11 consecutive hours. Red blood cell (RBC) counts, red cell distribution width (RDW), white blood cell (WBC) counts, platelets, mean platelet volume (MPV) and hemoglobin were obtained using an automated veterinary cell counter. Hematocrit (HTC) was determined by Strumia's microcapillary method, differential leukocyte count was performed on hematological dye-stained blood smears and
\end{abstract}

\footnotetext{
1 Médicas Veterinárias, Programa de Aprimoramento Profissional em Medicina Veterinária, Área Laboratório Diagnóstico Veterinário, Centro Universitário das Faculdades Integradas de Ourinhos, Unifio, Ourinhos, SP, Brasil. E-mail: leticia_le05@, hotmail.com; paula.aaspa@gmail.com

2 Médica Veterinária, Programa de Residência Multiprofissional em Medicina Veterinária, Área Laboratório Clínico Veterinário, Faculdade Medicina Veterinária de Araçatuba, FMVA, UNESP, Araçatuba, SP, Brasil. E-mail: nathaliavetfio@gmail.com

3 Discente, Curso de Mestrado do Programa de Pós-Graduação em Ciência Animal, Universidade Estadual de Londrina, UEL, Londrina, PR, Brasil. E-mail: natalia.minucci@gmail.com

4 Médico Veterinário. Programa de Aprimoramento Profissional em Medicina Veterinária, Área Clínica Cirúrgica de Pequenos Animais, Centro Universitário das Faculdades Integradas de Ourinhos, Unifio, Ourinhos, SP, Brasil. E-mail: guilhermecouvieira@, gmail.com

5 Profs. Drs., Curso de Graduação em Medicina Veterinária, Centro Universitário das Faculdades Integradas de Ourinhos, Unifio, Ourinhos, SP, Brasil.E-mail: biapflor@gmail.com; bfmalmeida@yahoo.com.br

6 Prof. Dr., Curso de Graduação em Medicina Veterinária, UEL, Londrina, PR, Brasil. E-mail: luizdanielbarros@gmail.com

7 Farmacêutica, Hospital Veterinário "Roque Quagliato", Centro Universitário das Faculdades Integradas de Ourinhos, Unifio, Ourinhos, SP, Brasil. E-mail: mariarachelmb@gmail.com

* Author for correspondence
} 
total plasma protein (TPP) was determined using refractometry. Variables were tested for normality and differences were considered significant when $\mathrm{p}<0.05$. A statistically significant decrease was observed in the erythrogram from $2 \mathrm{~h}$ for $\mathrm{RBC}$ and hemoglobin, from $3 \mathrm{~h}$ for $\mathrm{HTC}$ and from $4 \mathrm{~h}$ for $\mathrm{MCV}$, persisting until the end of 11 hours. There was no change in MCHC and RDW. Regarding the leukogram, a significant increase in WBC was observed from 2 to $7 \mathrm{~h}$, due to the increase in segmented neutrophils 2 to $8 \mathrm{~h}$ following feeding. Lymphocyte counts decreased significantly at 2 and $6 \mathrm{~h}$ following feeding. No alteration was observed in eosinophil, basophil, monocyte and platelet counts, as well as in MPV. From $5 \mathrm{~h}$ to $11 \mathrm{~h}$ after feeding, a significant decrease was seen on TPP. However, changes in hematological parameters did not exceed reference ranges for the canine species. Feeding dogs with industrialized feed caused statistically significant changes in erythrogram, leukogram and plasma protein content. While these changes do not seem to exceed reference values for the species in healthy animals, caution is warranted for sick animals with borderline values, in which these changes might be clinically important depending on the pathologic process.

Key words: Complete blood count. Dog. Food.

\section{Resumo}

O hemograma é a avaliação das células do sangue e fornece grande diversidade de informações. Considerando que o tempo inadequado de jejum é o erro pré-analítico mais comum no diagnóstico laboratorial por causar lipemia nas amostras sanguíneas e tal interferência ainda não foi adequadamente investigada no hemograma de cães, esse trabalho teve como objetivo analisar as alterações pós-prandiais diurnas no hemograma de cães saudáveis alimentados com ração comercial. Foram selecionados 18 cães clinicamente saudáveis, entre 2 e 6 anos, pesando mais de $6 \mathrm{~kg}$ e que recebiam como alimentação ração comercial tipo "Premium" a cada 12 horas. O sangue dos animais foi colhido após jejum de 12 horas às 6:00 da manhã (amostra basal), foi fornecida ração comercial e novas amostras foram colhidas nas 11 horas consecutivas. As contagens de hemácias, amplitude de distribuição eritrocitária (RDW), leucócitos totais, plaquetas, volume plaquetário médio (VPM) e hemoglobina foram realizadas em contador automatizado de células veterinário. O volume globular $(\mathrm{VG})$ foi determinado pelo método do microcapilar de Strumia, a contagem diferencial de leucócitos foi realizada em esfregaço sanguíneo corado com corante hematológico e a proteína plasmática total (PPT) foi determinada por refratometria. As variáveis foram testadas quanto à normalidade e as diferenças foram consideradas significativas quando $\mathrm{p}<0,05$. Em relação ao eritrograma, houve redução estatisticamente significativa a partir de $2 \mathrm{~h}$ para hemácias e hemoglobina, a partir de $3 \mathrm{~h}$ para o VG e a partir de $4 \mathrm{~h}$ para o VCM, persistindo até o final das 11 horas. Não houve alteração do CHCM e do RDW. Em relação ao leucograma, foi observado aumento significativo de leucócitos totais de $2 \mathrm{a} 7 \mathrm{~h}$, decorrente do aumento de neutrófilos segmentados, o que foi constatado 2 a $8 \mathrm{~h}$ após a alimentação. $\mathrm{O}$ valor de linfócitos reduziu significativamente nos momentos 2 e $6 \mathrm{~h}$ após a alimentação. Não foi observada alteração nas contagens de eosinófilos, basófilos, monócitos e plaquetas, bem como no VPM. Os níveis de PPT reduziram significativamente de $5 \mathrm{~h}$ até $11 \mathrm{~h}$ após a alimentação. Contudo, tais alterações nos parâmetros hematológicos não excederam os valores de referência para a espécie canina. A alimentação com ração comercial causa alterações estatisticamente significativas no eritrograma, leucograma e teor de proteína plasmática em cães. Para animais saudáveis, tais alterações parecem não exceder valores de referência para espécie, porém para animais enfermos com valores limítrofes, tais alterações poderiam ser clinicamente importantes dependendo da patologia envolvida.

Palavras-chave: Hemograma. Cão. Alimento. 


\section{Introduction}

Complete blood count (CBC) is the evaluation of blood components, comprised of the erythrogram, leukogram and assessment of platelets and plasma proteins (Grotto, 2009; Lopes, Biondo, \& Santos, 2007). This test provides a great diversity of information, often unspecific but extremely important, thereby rendering the $\mathrm{CBC}$ the main screening test and one of the most requested tests in clinical and surgical practices, mainly due to its practicality, low cost and usefulness. The CBC offers a general overview of the clinical status of the animal, rarely presenting a definitive diagnosis for any pathology, but rather providing data that aids the interpretation of various physiological and pathological situations, always in association with clinical signs and other tests (Grotto, 2009).

Any laboratory analysis is comprised of three phases: pre-analytical, analytical and post-analytical phase. Analyses begin with the choice of a certain exam, preparation of the patient, collection, correct identification of the sample, transport and its preparation for analysis, after which the result is reported and interpreted, when a decision will be made (Lippi et al., 2011). Most errors in laboratory diagnosis occur in the pre-analytical phase, a phase that covers a wide range of operations (Almeida et al., 2011; Lippi et al., 2011).

Inadequate fasting time before blood sample collection is the most common error, leading to lipemia in blood samples. This postprandial lipemia can cause errors in laboratory analyses, especially biochemical analyses (Nikolac, 2014). However, little is known about the influence of postprandial lipemia on hematological parameters, especially in dogs. Thus, adequate fasting before blood sampling for biochemical evaluation is essential, otherwise there may be irreparable damage such as wrong results and incorrect medical decision, compromising patient safety. In this regard, the clinician should know which laboratory errors may occur due to lipemia in blood samples (Guidi,
Simundic, Salvagno, Aquino, \& Lima-Oliveira, 2014). Chylomicrons are the largest lipoproteins and have lower density, causing turbidity of the serum when present in large quantities, which leads to the emergence of postprandial lipemia (Thrall, Weiser, Allison, \& Campbell, 2012).

Kackov, Simundic and Gatti-Drnic (2013) reported that $39 \%$ of human patients interviewed in a laboratory claimed to know the definition of fasting and $46 \%$ believed that the time of the last meal was not important as long as it was the day before. By extrapolating this data to veterinary medicine, the scenario may be even worse, making postprandial lipemia a barrier to the quality of laboratory results.

Previous studies evaluating the effect of postprandial lipemia on hematological parameters in human volunteers have reported leukogram alterations (Cheng et al., 2010; Hansen, Sickelmann, Pietrowsky, Fehm, \& Born, 1997; Klop et al., 2013; Lippi et al., 2010; Pavlishchuk, Petrik, \& Nikol'skaya, 2004; Van Oostrom et al., 2002; Van Oostrom, Sijmonsma, Rabelink, Asbeck, \& Cabezas, 2003; Van Oostrom et al., 2004), mainly associated with increased white blood cell (WBC) count due to increased neutrophil count (Lippi et al., 2010; Van Oostrom et al., 2002, 2003, 2004). Lymphocyte count varies among studies, with some reporting increased count (Klop et al., 2013; Van Oostrom et al., 2002, 2003, 2004), while others have reported decreased number due to food intake (Hansen et al., 1997; Lippi et al., 2010). Erythrogram alterations have also been reported by Lippi et al. (2010), who observed decreased erythrocytes, hemoglobin, hematocrit and mean corpuscular volume following a light meal, while Hansen et al. (1997) observed increased hemoglobin and hematocrit after a high fat diet in humans. To date, such studies have not been reported in dogs.

Considering the scarcity of studies evaluating the interference of postprandial lipemia on canine hematological parameters, the aim of the present study was to evaluate diurnal $\mathrm{CBC}$ alterations in healthy dogs fed with industrialized feed. 


\section{Materials and Methods}

Approval by the ethics committee

All procedures were approved by the Centro Universitário das Faculdades Integradas de Ourinhos (Unifio) Animal Usage Ethics Committee (protocol No. 023/2016). Owners were asked to sign an informed consent form allowing inclusion of dogs in the study.
Animal selection and blood sampling

Eighteen healthy dogs with no clinical, hematological and biochemical changes, aged 2-6 years and weighing more than $6.0 \mathrm{~kg}$ with a body condition score between 4 and 5 (Laflamme, 1997) were enrolled in the study (Table 1). One week before inclusion, all dogs underwent $\mathrm{CBC}$ and serum biochemical assessment to prove their health as shown on Table 1.

Table 1

Hematological and biochemical parameters (mean \pm standard deviation) of healthy dogs included in the study $(\mathbf{n}=18)$

\begin{tabular}{|c|c|c|}
\hline Parameter & Result & Reference range \\
\hline \multicolumn{3}{|c|}{ Hematology } \\
\hline Hematocrit (\%) & $51.1 \pm 3.40$ & $37-55$ \\
\hline $\mathrm{RBC}\left(10^{12} / \mathrm{L}\right)$ & $7.12 \pm 0.54$ & $5.5-8.5$ \\
\hline Hemoglobin (g/dL) & $16.2 \pm 1.57$ & $12-18$ \\
\hline MCV (fL) & $71.3 \pm 1.2$ & $60-77$ \\
\hline MCHC (\%) & $33.7 \pm 1.2$ & $32-36$ \\
\hline $\operatorname{WBC}\left(10^{9} / \mathrm{L}\right)$ & $9.37 \pm 1.34$ & $6.0-17.0$ \\
\hline Segmented neutrophils $\left(10^{6} / \mathrm{L}\right)$ & $5567 \pm 912$ & $3000-11500$ \\
\hline Lymphocytes $\left(10^{6} / \mathrm{L}\right)$ & $2536 \pm 635$ & $1000-4800$ \\
\hline Monocytes $\left(10^{6} / \mathrm{L}\right)$ & $281 \pm 136$ & $150-1350$ \\
\hline Eosinophils $\left(10^{6} / \mathrm{L}\right)$ & $991 \pm 612$ & $150-1250$ \\
\hline Basophils $\left(10^{6} / \mathrm{L}\right)$ & $0 \pm 0$ & Rare \\
\hline Platelet $\left(10^{9} / \mathrm{L}\right)$ & $331.3 \pm 45.3$ & $160-430$ \\
\hline \multicolumn{3}{|c|}{ Clinical biochemistry } \\
\hline Total protein (g/dL) & $6.43 \pm 0.33$ & $5.4-7.1$ \\
\hline Albumin (g/dL) & $3.12 \pm 0.22$ & $2.6-3.3$ \\
\hline Globulin (g/dL) & $3.18 \pm 0.88$ & $2.7-4.4$ \\
\hline ALT (IU/L) & $52.5 \pm 29.3$ & $21-102$ \\
\hline AST (IU/L) & $31.1 \pm 9.1$ & $23-66$ \\
\hline ALP (IU/L) & $62.3 \pm 17.3$ & $20-156$ \\
\hline Total cholesterol (mg/dL) & $168.3 \pm 17.1$ & $135-270$ \\
\hline Triglycerides (mg/dL) & $75.5 \pm 13.2$ & $20-112$ \\
\hline Glucose (mg/dL) & $85.3 \pm 7.5$ & $68-118$ \\
\hline Urea (mg/dL) & $32.3 \pm 2.1$ & $10-50$ \\
\hline Creatinine (mg/dL) & $1.09 \pm 0.14$ & $0.5-1.5$ \\
\hline
\end{tabular}

Abbreviations: ALT: Alanine Aminotransferase; ALP: alkaline phosphatase; AST: aspartate aminotransferase; MCHC: mean corpuscular hemoglobin concentration; MCV: mean corpuscular volume; RBC: red blood cells; WBC: white blood cells. Canine reference values according to Rizzi, Meinkoth and Clinkenbeard (2010) for hematology and Kaneko, Harvey and Bruss (2008) for clinical biochemistry. 
All subjects were fed exclusively with "Premium" commercial feed as indicated on the manufacturer's daily recommendations for the twice-a-day feeding regimen. Feed ration was comprised of a minimum of $26 \%$ crude protein and $14 \%$ ethereal extract, maximum of $2.5 \%$ dry matter and $7.5 \%$ mineral mixture and metabolizable energy of $3,730 \mathrm{kcal} /$ kg (CIBAU Adult Medium Breeds, Farmina Pet Foods, São Paulo, Brazil). Considering that the dogs included in the experiment were adults and had normal physical activity (dogs were not sedentary or sports practitioners), each dog received $8.3 \mathrm{~g} / \mathrm{kg}$ of feed per meal.

To verify the effect of feeding on hematological parameters, dogs were transported to the Roque Quagliato Veterinary Teaching Hospital and had the first blood sample collected after a 12-hour fasting at 6:00 am (baseline sample, $0 \mathrm{~h}$ ). Commercial ration $(8.3 \mathrm{~g} / \mathrm{kg})$ was then provided and new blood samples were obtained $1,2,3,4,5,6,7,8,9,10$ and 11 hours following feeding. All animals ate all provided food within 10 minutes. Subjects were kept in individual kennels ( $1 \times 1 \times 0.5 \mathrm{~m})$ with water ad libitum during the experiment.

Prior to blood collection, the jugular vein was catheterized and the catheter was flushed with heparinized physiological solution (5 IU/mL). At each blood sampling, $1 \mathrm{~mL}$ of the heparinized physiological solution of the catheter was discarded and $2 \mathrm{~mL}$ of blood were collected into potassium ethylenediaminetetraacetic acid tubes (EDTA-K2, Injex Vacuum, Injex Industries Surgical, Ourinhos, SP, Brazil). All samples were processed immediately following collection.

\section{Laboratory analysis}

To perform the $\mathrm{CBC}$, red blood cell counts (RBC), red blood cell distribution width (RDW), total white blood cell counts (WBC), platelets, mean platelet volume (MPV), and hemoglobin were measured using an automated veterinary cell counter (ABX Micros ESV 60, Paris, France). Hematocrit (HTC) was determined by Strumia's microcapillary method (11,400 rpm for 5 minutes) and differential leukocyte count was performed on a commercial hematological stain-stained blood smear (InstantProv, Newprov, Pinhais, PR, Brazil), following the recommendations of Jain (1986). Total plasma protein (TPP) was determined using a portable clinical refractometer (ATAGO, Mod. Master-SURNM, Tokio, Japan). Hematimetric indices mean corpuscular hemoglobin concentration (MCHC) and mean corpuscular volume (MCV) were calculated as described previously (Jain, 1986).

Biochemical analyses were performed in duplicate at $37^{\circ} \mathrm{C}$ using a semiautomated spectrophotometer (BIO 2000, BioPlus, São Paulo, Brazil) with a set of commercial reagents (Labtest Diagnóstica SA, Minas Gerais, Brazil) according to manufacturer recommendations. Calibration was performed prior to analyses (Calibra H, Labtest Diagnóstica SA, Minas Gerais, Brazil) and verified using commercial control levels I (Qualitrol 1H, Labtest Diagnóstica SA, Minas Gerais, Brazil) and II (Qualitrol 2H, Labtest Diagnóstica SA, Minas Gerais, Brazil). Glucose, total cholesterol and triglyceride levels were performed using Trinder's enzymatic methods, alanine aminotransferase (ALT) and aspartate aminotransferase (AST) activities were measured using ultraviolet kinetic (UV) methodology, albumin was determined by bromocresol green colorimetric method, creatinine by alkaline picrate colorimetric method - Jaffé, alkaline phosphatase (ALP) by the modified Bowers and McComb kinetic method, total proteins by the biuret colorimetric method and urea was measured through UV enzymatic methodology. Globulin was obtained from albumin subtraction of total proteins.

\section{Statistical analysis}

Data were first tested for normality using the Shapiro-Wilk test and the differences between the various times in relation to baseline were assessed through repeated measures ANOVA followed by Holm's or Dunnett's post-hoc test or Friedman's test followed by Dunn's post-hoc test. Analyses were 
performed using a computer software (GraphPad Prism, v.6.00 for Windows, GraphPad Software, La Jolla, CA, USA, www.graphpad.com) and considered significant when $\mathrm{p}<0.05$.

\section{Results and Discussion}

All dogs that concluded the study were clinically healthy, demonstrating hematological and biochemical parameters within normal range for the species (Table 1) according to Rizzi, Meinkoth and Clinkenbeard (2010) and Kaneko, Harvey and Bruss (2008), respectively.

Regarding the erythrogram, there was a decrease in RBC, hemoglobin, HTC and MCV over time, which was statistically significant from $2 \mathrm{~h}$ for $\mathrm{RBC}$ (Figure 1C) and hemoglobin (Figure 1B), from $3 \mathrm{~h}$ for HTC (Figure 1A) and from $4 \mathrm{~h}$ for MCV (Figure 1D). There was no change in MCHC (Figure 1E) and RDW (Figure 1F). Regarding the leukogram, a significant increase was observed in WBC from 2 to $7 \mathrm{~h}$ (Figure 2A) and segmented neutrophils from 2 to $8 \mathrm{~h}$ (Figure 2B) after feeding. Lymphocyte values decreased significantly at 2 and $6 \mathrm{~h}$ (Figure 2C) after feeding, while no change was observed in monocyte (Figure 2D), eosinophil (Figure 2E) and basophil (Figure 2F) counts. There were no significant changes in platelet count (Figure 3A) and MPV (Figure 3B). Levels of TPP significantly decreased from $5 \mathrm{~h}$ extending until $11 \mathrm{~h}$ following feeding.
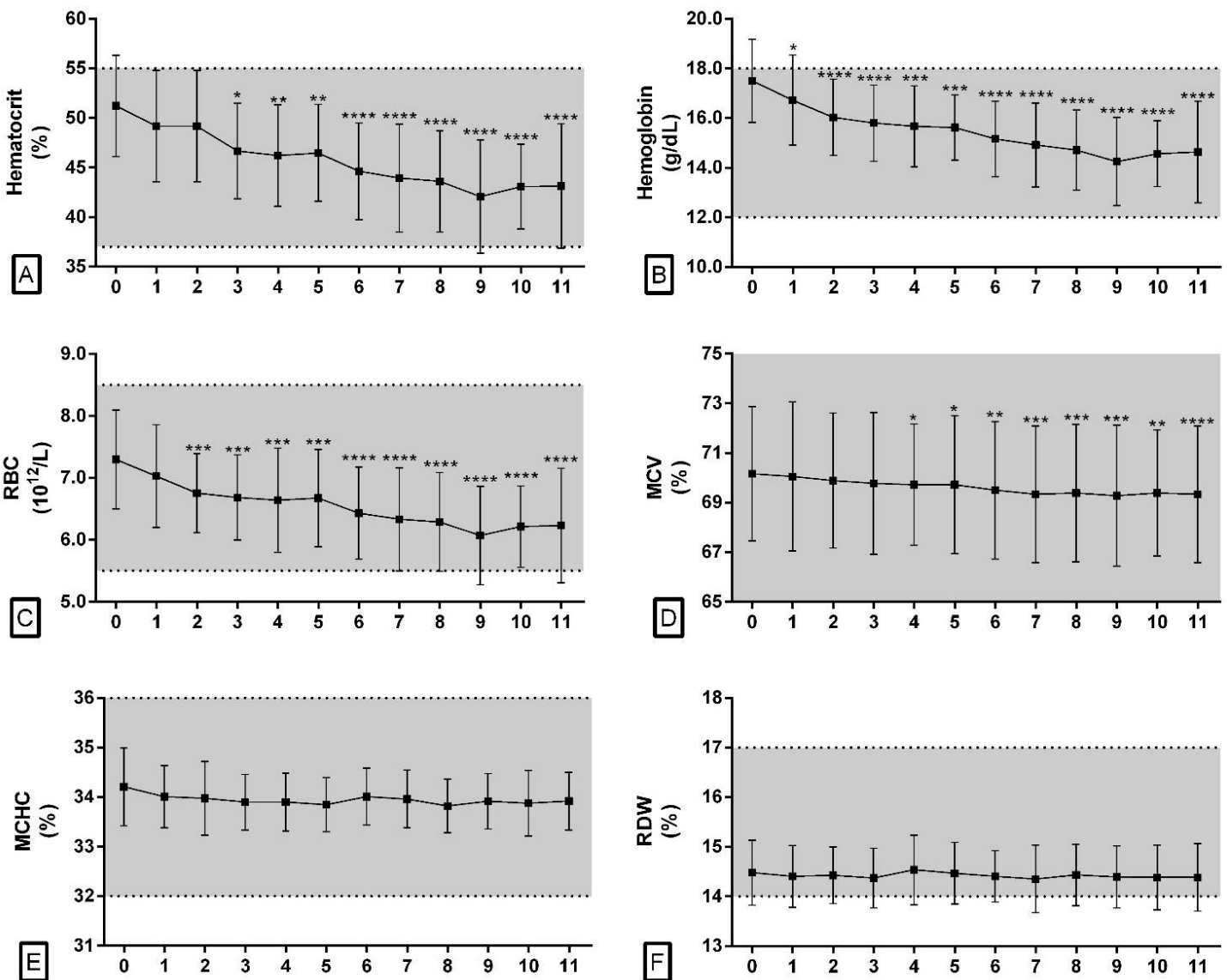

Figure 1. Hematocrit (HTC, A), hemoglobin (B), red blood cells (RBC, C), mean corpuscular volume (MCV, D), mean corpuscular hemoglobin concentration $(\mathrm{MCHC}, \mathbf{E})$ and Red blood cell distribution width width (RDW, F) in healthy dogs $(\mathrm{n}=18)$ after a 12-hour fasting (baseline time, $0 \mathrm{~h}$ ) and 1, 2, 3, 4, 5, 6, 7, 8, 9, 10 and 11 hours following feeding with commercial feed. Graphs are represented by mean and standard deviation, the statistically significant difference from baseline is indicated by $*(\mathrm{p}<0.05), * *(\mathrm{p}<0.01), * * *(\mathrm{p}<0.001)$ or $* * * *(\mathrm{p}<0.0001)$ and the dotted lines indicate the reference values according to Rizzi, Meinkoth and Clinkenbeard (2010). 

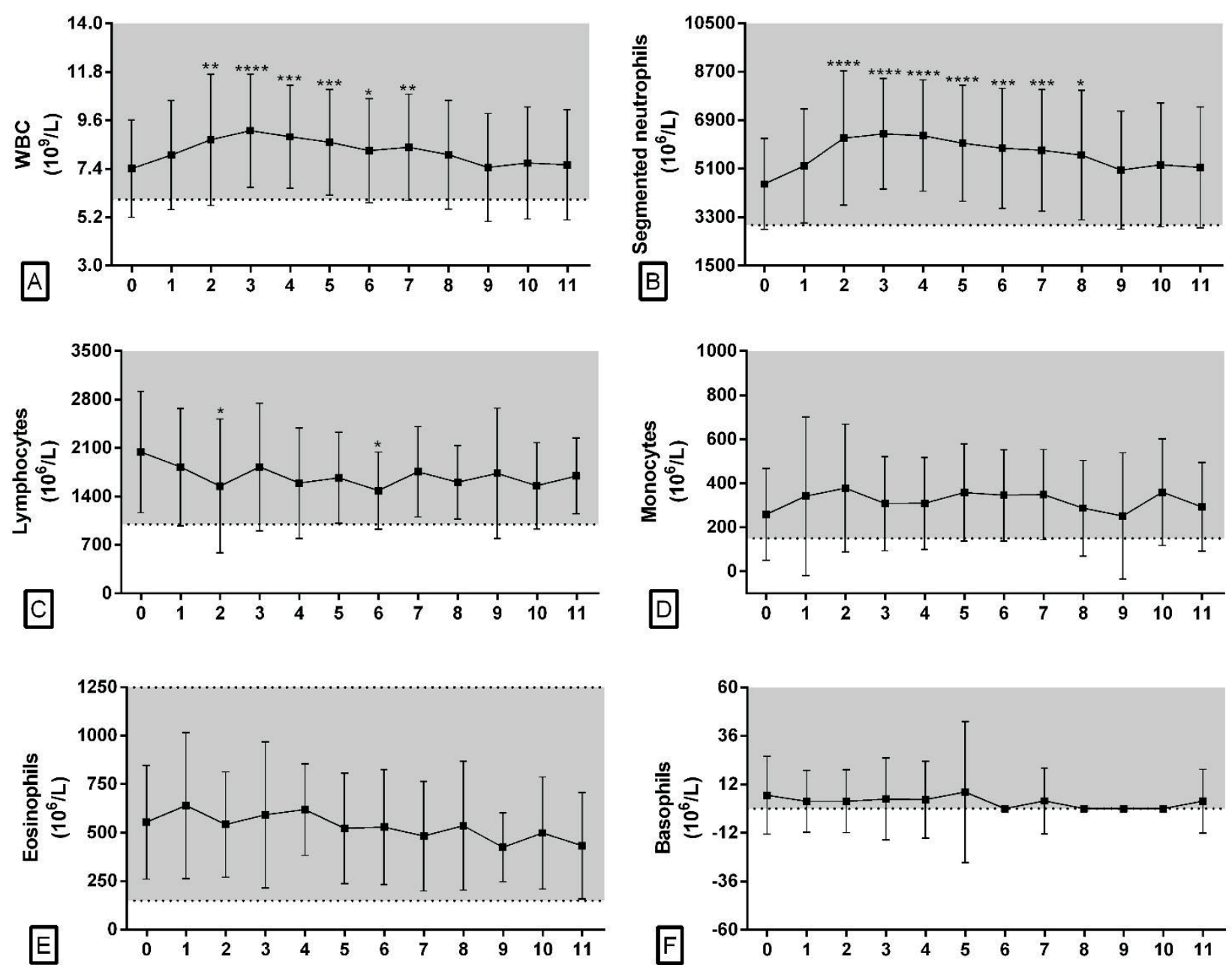

Figure 2. White blood cells (WBC, A), segmented neutrophils (B), lymphocytes (C), monocytes (D), eosinophils (E) and basophils $(\mathbf{F})$ in healthy dogs $(\mathrm{n}=18)$ after a 12-hour fasting (baseline time, $0 \mathrm{~h}$ ) and 1, 2, 3, 4, 5, 6, 7, 8, 9, 10 and 11 hours following feeding with commercial feed. Graphs are represented by mean and standard deviation, the statistically significant difference from baseline is indicated by * $(\mathrm{p}<0.05)$, ** $(\mathrm{p}<0.01), * * *(\mathrm{p}<0.001)$ or $* * * *(\mathrm{p}$ $<0.0001)$ and the dotted lines indicate the reference values according to Rizzi, Meinkoth and Clinkenbeard (2010). 

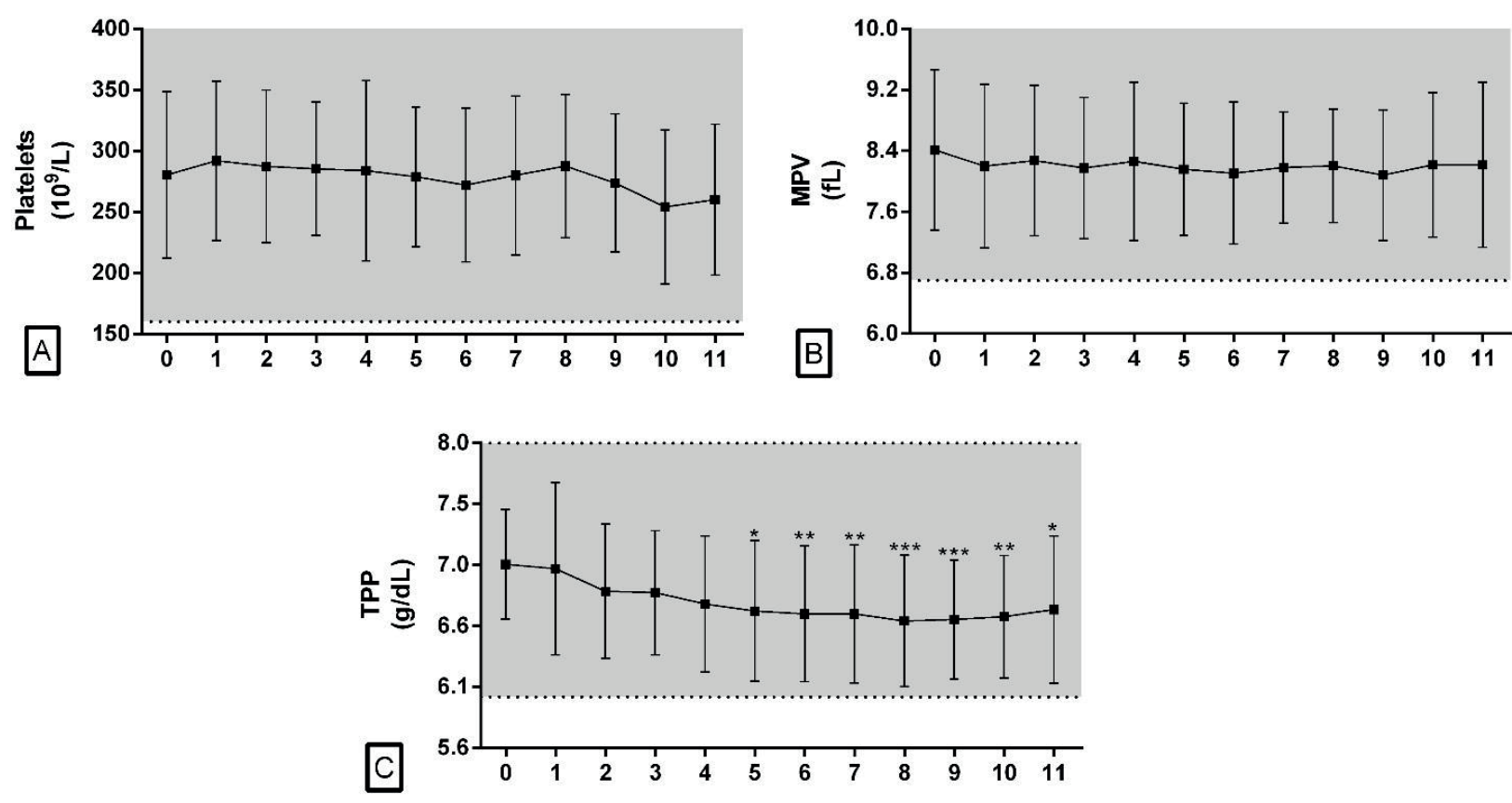

Figure 3. Platelets (A), mean platelet volume (MPV, B) and total plasma protein (TPP, C) in healthy dogs $(\mathrm{n}=$ 18) after a 12-hour fasting (baseline time, $0 \mathrm{~h}$ ) and 1, 2, 3, 4, 5, 6, 7, 8, 9, 10 and 11 hours following feeding with commercial feed. Graphs are represented by mean and standard deviation, the statistically significant difference from baseline is indicated by $*(p<0.05), * *(p<0.01), * * *(p<0.001)$ or $* * * *(p<0.0001)$ and the dotted lines indicate the reference values according to Rizzi, Meinkoth and Clinkenbeard (2010).

Complete blood count is often used as a screening laboratory test by veterinary practitioners, and thus the knowledge of factors that can interfere with this exam is essential for adequate assessment of the patient. Studies addressing the effect of postprandial lipemia on canine hematological parameters are scarce and, to date, we have not found studies concerned with this effect in animals fed with commercial ration. As postprandial changes, we observed a significant decrease in hemoglobin, RBC, HTC and plasma proteins following feeding. In humans, Lippi et al. (2010) also observed decreased $\mathrm{RBC}$ and HTC at $2 \mathrm{~h}$ and $4 \mathrm{~h}$ after eating a light meal, respectively. It is possible that the decrease may be explained by hemodilution that ensues after feeding (Korbonits, Blaine, Elia, \& Powell-Tuck, 2007). In humans, water intake in conjunction with food intake would have contributed to such findings (Lippi et al., 2010). In our experiment, dogs had samples taken early in the morning (6:00 am), when there would be hemoconcentration because animals were fasting and water intake is minimal during the early hours of the day. Following feeding, almost all dogs ingested water, although in variable amounts that could not be measured. Thus, similarly to what occurs in humans, feeding decreases red blood cells, although their numbers still remain within the reference values for the species. Animals with borderline values could demonstrate clinically significant reductions.

RBC from hyperlipidemic dogs have greater osmotic fragility (Behling-Kelly \& CollinsCronkright, 2014) and lipemia could contribute to in vitro hemolysis. However, such an effect was not observed in our samples, perhaps due to the short storage time and immediate analysis.

Postprandial lipemia did not cause significant changes in MCHC values in dogs fed with commercial ration. This parameter is calculated using HTC and hemoglobin, the latter being determined by spectrophotometry in automated 
hematological counters (Andrade, Oliveira, \& Souza, 2016). Considering that lipemia directly interferes with light absorption (Nikolac, 2014; Silva et al., 2019), it would be plausible to assume that lipemic samples had higher MCHC because hemoglobin values were overestimated. However, in our study, hemoglobin levels were the first to decrease due to feeding, remaining low until 11 hours after feeding. It is possible that the degree of lipemia induced by commercial ration is not enough to cause such errors in the determination of $\mathrm{MCHC}$ in dogs.

MCV significantly decreased from $4 \mathrm{~h}$ after feeding without significant change in RDW. One can then assume that the decreased red blood cell volume is related to extracellular osmotic pressure, especially an increase in sodium concentrations following feeding, which would attract fluid from RBC due to its osmotic activity, thereby contributing to decrease its volume (Korbonits et al., 2007), also decreasing RBC, hemoglobin, HTC and proteins, as observed in the present study. Corroborating this hypothesis, the reduction of MCV without changes on RDW suggests that this volume decrease occurred uniformly in RBC, without significant volume variation among them.

Regarding the leukogram, we observed a significant increase in WBC due to the increase in segmented neutrophils counts, which occurred at 2 $\mathrm{h}$ after feeding and remained until $8 \mathrm{~h}$. In human reports, leukocytosis is reported as a postprandial inflammation, in which uptake of triglyceriderich lipoproteins leads to increased adhesion and endothelial activation. As a result, migration of inflammatory cells and lipoproteins to the subendothelium may be increased (Van Oostrom et al., 2003; Alipour et al., 2008). Klop et al. (2013) also observed that monocytes and neutrophils from healthy adult humans are activated after a meal. but postprandial leukocyte activation is temporary, yet similar to changes seen in various infections, to a lesser extent. Similarly, as dogs have also demonstrated increased segmented neutrophils, further studies are needed to confirm activation of these cells and whether it could contribute to postprandial oxidative stress, as suggested in humans (Alipour et al., 2008).

Lippi et al. (2010) observed that even a light meal was enough to cause intestinal exposure to antigens and, consequently, produce lymphocyte migration to promote local immunity, which was accompanied by bone marrow mobilization or neutrophil demarginalization. However, in dogs, there may be other factors that contribute to increased WBC and segmented neutrophils. One of these factors would be physiological leukocytosis that occurs in dogs following stimulation such as fear or strenuous exercise (Weiss \& Wardrop, 2010). In situations of excitation, epinephrine is released and causes cardiovascular events which in turn lead to increased blood flow through microcirculation causing neutrophils to be released from the marginal compartment into the circulating compartment, leading to neutrophilia (Weiss \& Wardrop, 2010; Thrall et al., 2012). Given that the dogs in the experiment were removed from their homes and kept in a strange environment and manipulated by strangers, it is possible that, at least in part, physiological leukocytosis contributed to the initial increase in segmented neutrophils and, as a resut, total leukocytes (Lopes et al., 2007).

It is unlikely that a single factor contributed to increase WBC postprandially in dogs as well as in humans (Lippi et al., 2010), as physiological leukocytosis usually progresses to lymphocytosis and we observed a significant decrease in lymphocytes 2 and $6 \mathrm{~h}$ after food intake. Human studies suggest that this phenomenon is due to the distribution and function of immune cells, and decreased lymphocytes and monocytes observed in humans after feeding reflect migration of these cells to lymphoid tissues to support primary immune responses in the gut (Hansen et al., 1997; Van Oostrom, 2002, 2003; Cheng et al., 2010; Lippi et al., 2010). In our study, it is also possible that the stress caused by manipulation 
of the animals led to the release of cortisol by the adrenal gland and, consequently, contributed to the increase in segmented neutrophils associated with lymphopenia, the so-called stress leukogram. Steroids alter the recirculation pattern of leukocytes and may lead to apoptosis and lymphocyte sequestration to extravascular sites. There is also duplication of circulating neutrophils, as there is a decrease in blood viscosity, in marginalization and consequent diapedesis of cells to tissues (Lopes et al., 2007; Thrall et al., 2012). Corroborating with this hypothesis, Hansen et al. (1997) reported increased postprandial cortisol levels in humans. Stress leukograms can also be observed in various systemic diseases, metabolic disorders, and conditions that cause pain. Eosinopenia in stress leukogram occurs mainly through a decreased output of these bone marrow cells due to interference with the chemotactic effect of histamine on eosinophils. Monocytosis occurs in dogs for unknown causes. The response of basophils to corticosteroids is similar to that of eosinophils but is not usually recognized because basophils are rare in the blood (Lopes et al., 2007). Seeing as such alterations were not observed in the present study since monocytes, eosinophils and basophils did not show changes in their count, it is likely that a combination of factors contributed to the alterations observed in the postprandial erythrogram and leukogram of dogs.

Platelet count and volume were not influenced by food intake of dogs, however, Pavlishchuk et al. (2004) reported that after feeding there may be an increase in plasma fibrinogen that modulates the early stages of platelet aggregation and its interrelation with other cells in humans, thus contributing to increased platelet aggregation. Corroborating these findings, Krüger, Farinha, Teixeira and Oliveira (2015) indicate that this response is probably due to endothelial dysfunction caused after eating. Taken together, these factors could contribute to postprandial platelet consumption. However, such alterations do not appear to occur, or they are not enough to decrease circulating platelet counts in dogs, and there are also few studies evaluating postprandial effects on hemostasis in dogs fed commercial ration.

\section{Conclusions}

The supply of commercial feed causes statistically significant alterations on the erythrogram, leukogram and plasma protein parameters of dogs. However, for healthy dogs, these changes do not appear to be clinically significant, but for ill animals with borderline values, they may be clinically relevant.

\section{Acknowledgements}

The authors are grateful to the São Paulo Research Foundation for the scholarships granted (FAPESP no. 2017/02641-4).

\section{References}

Alipour, A., Van Oostrom, A. J. H. H. M., Izraeljan, A., Verseyden, C., Collins, J. M., Frayn, K. N.,... Cabezas, M. C. (2008). Leukocyte activation by triglyceride-rich lipoproteins. Arteriosclerosis, Thrombosis, and Vascular Biology, 28(4), 792-797. doi: 10.1161/ATVBAHA.107.159749

Almeida, B. F. M., Zucatto, A. S., Vieira, R. F. C., Soeiro, C. S., Viol, M. A., Bomfim, S. R. M., \& Ciarlini, P. C. (2011). Effect of hemolysis on canine, bovine and equine serum chemistry. Medicina Veterinária, 5(1), 12-17.

Andrade, N. N. N., Oliveira, M. V., \& Souza, C. L. (2016). Procedures to minimize interference of hypertriglyceridemia in laboratory exams of lipemic samples in acute pancreatitis: a case report. Jornal Brasileiro de Patologia e Medicina Laboratorial, 52(2), 103-106. doi: 10.5935/1676-2444.20160022

Behling-Kelly, E., \& Collins-Cronkright, R. (2014). Increases in beta-lipoproteins in hyperlipidemic and dyslipidemic dogs are associated with increased erythrocyte osmotic fragility. Veterinary Clinical Pathology, 43(3), 405-415. doi: 10.1111/vcp.12155

Cheng, Y. C., Kao, W. H. L., Mitchell, B. D., Sharrett, A. R., Ryan, K. A., Vogel, R. A.,... Pollin, T. I. (2010). Genetic effects on postprandial variations of inflammatory markers in healthy individuals. Obesity, 18(7), 1417-1422. doi: 10.1038/oby.2009.416 
Grotto, H. Z. W. (2009). O hemograma: importância para a interpretação da biópsia. Revista Brasileira de Hematologia e Hemoterapia, 31(3), 178-182. doi: $10.1590 / \mathrm{S} 1516-84842009005000045$

Guidi, G. C., Simundic, A. M., Salvagno, G. L., Aquino, J. L., \& Lima-Oliveira, G. (2014). To avoid fasting time, more risk than benefits. Clinical Chemistry and Laboratory Medicine, 53(10), e261-4. doi: 10. 1515/ cclm-2014-1013

Hansen, K., Sickelmann, F., Pietrowsky, R., Fehm, H. L., \& Born, J. (1997). Systemic immune changes following meal intake in humans. American Journal of Physiology, 273(2), 548-553. doi: 10.1152/ ajpregu.1997.273.2.R548

Jain, N. C. (1986). Hematologic Techniques. In: N. C. Jain (Ed.), Schalm's Veterinary Hematology, (2nd ed., pp. 20-86). Philadelphia: Wiley-Blackwell.

Kackov, S., Simundic, A. M., \& Gatti-Drnic, A. (2013). Are patients well informed about the fasting requirements for laboratory blood testing? Biochemia Medica, 23(3), 326-331. doi: 10.11613/ BM. 2013. 040

Kaneko, J. J., Harvey, J. W., \& Bruss, M. L. (2008). Clinical biochemistry of domestic animals (6nd ed.). London: Academic Press.

Klop, B., Vandegeijn, G. J. M., Njo, T. L., Janssen, H. W., Rietveld, A. P., Van Miltenburg, A.,... Cabezas, M. C. (2013). Leukocyte cell population data (volume conductivity scatter) in postprandial leukocyte activation. International Journal of Laboratory Hematology, 35(6), 644-651. doi: 10.1111/ ijlh. 12103.

Korbonits, M., Blaine, D., Elia, M., \& Powell-Tuck, J. (2007). Metabolic and hormonal changes during the refeeding period of prolonged fasting. European Journal of Endocrinology, 157(6), 157-166. doi: 10. 1111/ijlh.12103

Krüger, R. L., Farinha, B. J., Teixeira, B. C., \& Oliveira, A. R. (2015). Oxidative stress and endothelial function: effects of physical exercise on results of postprandial lipemia. Jornal Vascular Brasileiro, 14(4), 328-340. doi: 10.1590/1677-5449.01715

Laflamme, D. (1997). Development and validation of a body condition score system for dogs. Canine Practice, 22(5-6), 10-15.

Lippi, G., Chance, J. J., Church, S., Dazzi, P., Fontana, R., Giavarina, D.,... Simundic, A. M. (2011). Preanalytical quality improvement: from dream to reality. Clinical Chemistry and Laboratory Medicine, 49(7), 1113-1126. doi: 10.1515/CCLM.2011.600
Lippi, G., Lima-Oliveira, G., Salvagno, G. L., Montagnana, M., Gelati, M., Picheth, G.,... Guidi, G. C. (2010). Influence of a light meal on routine haematological tests. Blood Transfusion, 8(2), 9499. doi: 10.1515/CCLM.2011.600

Lopes, S. T. A., Biondo, A. W., \& Santos, A. P. (2007). Manual de patologia clínica veterinária. Santa Maria: UFRGS.

Nikolac, N. (2014). Lipemia: causes, interference mechanisms, detection and management. Biochemia Medica, 24(1), 57-67. doi: 10.11613/BM.2014.008

Pavlishchuk, S. A., Petrik, G. G., \& Nikol'skaya, L. F. (2004). Relationships between platelets and blood cells in postprandial glycemia in healthy individuals. Human Physiology, 30(3), 349-352. doi: 10.1023/ B:HUMP.0000029185.12999.da

Rizzi, T. E., Meinkoth, J. H., \& Clinkenbeard, K. D. (2010). Normal hematology of the dog. In D. J. Weiss, K. J. Wardrop (Eds.), Schalm's veterinary hematology (6th ed., pp. 799-810). Philadelphia: Wiley-Blackwell.

Silva, N. L. T., Bonatto, N. C. M., Oliveira, P. L., Vieira, G. C., Floriano, B. P., Barros, L. D.,... Almeida, B. F. M. (2019). Post-prandial lipemia and glycemia in dogs fed with industrialized pet food. Comparative Clinical Pathology, 28(1), 253-258. doi: 10.1007/ s00580-018-2824-0

Thrall, M.A., Weiser, G., Allison, R. W., \& Campbell, T. W. (2012). Veterinary hematology and clinical chemistry (2nd ed.). Ames: John Wiley \& Sons.

Van Oostrom. A. J., Rabelink, T. J., Verseyden, C., Sijmonsma, T. P., Plokker, H. W., De Jaegere, P. P., \& Cabezas, M. C. (2004). Activation of leukocytes by postprandial lipemia in healthy volunteers. Atherosclerosis, 177(1), 175-182. doi: 10.1016/j. atherosclerosis.2004.07.004

Van Oostrom, A. J., Sijmonsma, T. P., Rabelink, T. J., van Asbeck, T. J., \& Cabezas, M. C. (2003). Postprandial leukocyte increase in healthy subjects. Metabolism, 52(2), 199-202. doi: 10.1053/ meta.2003.50037

Van Oostrom, A. J., Sijmonsma, T. P., Verseyden, C., Jansen, E. H. J. M., Koning, E. J. P., Rabelink, T. J., \& Cabezas, M. C. (2002). Postprandial recruitment of neutrophils may contribute to Endothelial dysfunction. Journal of Lipid Research, 44(3), 576583. doi: 10.1194/j1r.M200419-JLR200

Weiss, D. J., \& Wardrop, J. (2010). Schalm's veterinary hematology (6nd ed.). Ames: Blackwell Publishing Ltd. 
